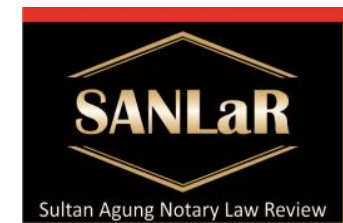

Volume 2 No. 4, December 2020
Sultan Aqung

Notary Law Review

Analysis of the Authority of...( Virginia Puspa Dianti)

\title{
Analysis of the Authority of the Substitute Notary Public in Preparing a Cooperative Establishment Deed
}

\author{
Virginia Puspa Dianti ${ }^{*}$, Jawade Hafidz ${ }^{* *}$ and Amin Purnawan ${ }^{* * *}$ )
}

*) Student of Master of Notary Law, Faculty of Law, Universitas Islam Sultan Agung (UNISSULA) Semarang, E-mail: virginiapuspad@gmail.com

$\left.{ }^{* *}\right)$ Lecturer of Master of Notary Law, Faculty of Law, Universitas Islam Sultan Agung (UNISSULA) Semarang

$\left.{ }^{* * *}\right)$ Lecturer of Master of Notary Law, Faculty of Law, Universitas Islam Sultan Agung (UNISSULA) Semarang

\begin{abstract}
The main objective of cooperatives is established as regulated in Article 4 of Act No 17 of 2012 to improve the welfare of Members in particular and society in general, as well as as an inseparable part of a democratic and just national economic order. The formulation of the problem in this research is how to implement the establishment of a Cooperative deed according to Act No 17 of 2012? And does the substitute notary have the authority to make a cooperative deed? The type of research used by the author is normative legal research by examining library materials related to the authority of the substitute notary in making cooperative establishment deeds based on a qualitative approach. Sources and types of data in this study were obtained through secondary data. To obtain the necessary data, the author collects laws and regulations relating to the title that the author takes. In addition, the author can obtain information through searching books and scientific works of legal experts. In this case the Author analyzes the Authority of the Substitute Notary in Preparing the Cooperative Establishment Deed. From this research, the author obtained the following results: (1) The establishment of a Cooperative is carried out by means of a Cooperative Establishment Deed made by a Notary registered at the Ministry of Cooperatives in Indonesian. (2) Substitute Notary Public can also make a Cooperative Deed of Establishment as long as the Substitute Notary is registered with the Ministry that administers Government affairs in the field of cooperatives.
\end{abstract}

Keywords: Authority; Substitute Notary Public; Making Cooperative Establishment Deed.

\section{Introduction}

The increasing need for life in Indonesia requires people to be able to improve the economy in order to live a better life. One form of community effort is to be able to improve the economy by increasing business activities which are felt to have a direct impact on improving the quality of life of the community. To assist in improving the 
community's economy, there is a cooperative which is expected to play a major role in improving the Indonesian economy.

Cooperatives are based on activities based on the principles of the people's economic movement based on the principle of kinship. Cooperatives come from Latin, namely 'coopere' which in English is called 'cooperation'. Co means 'together', while operation means 'work'. So in terminology, cooperation or cooperation can be interpreted as 'cooperation'. Meanwhile, according to the KBBI (Big Indonesian Dictionary) is an association which aims to meet the needs of its members by selling daily necessities at low prices and does not intend to make a profit. ${ }^{1}$.

Cooperatives themselves are regulated in Act No 25 of 1992 concerning Cooperatives, however this law was revoked and declared no longer valid by the Constitutional Court and replaced by Act No 17 of 2012 concerning Cooperatives. In this law, the meaning of cooperative is contained in Article 1 number 1 which reads as follows:

"A cooperative is a legal entity established by an individual or a cooperative legal entity, with the separation of the assets of its members as capital to run a business, which fulfills the common aspirations and needs in the economic, social and cultural fields in accordance with the values and principles of the cooperative."

The main objective of cooperatives is established as stipulated in Article 4 of Act No 17 of 2012 to improve the welfare of Members in particular and society in general, as well as as an inseparable part of a democratic and just national economic order.

In the process of establishing a Cooperative, prospective founders who deliberately gather in a place at a certain time are given an explanation by the Officer from the Service or Cooperative Office in the City or Regency so that the prospective founders understand the provisions governing the Cooperative, the objectives and rules of the Cooperative game. ${ }^{2}$. According to Article 7 of Act No 17 of 2012 concerning Cooperatives, cooperatives are divided into 2 (two) namely:

1. Primary Cooperatives are established by at least 20 (twenty) individuals by separating part of the assets of the founder or members as the initial capital of the Cooperative; and

2. Secondary Cooperatives are established by at least 3 (three) Primary Cooperatives.

Regarding the establishment of a Cooperative, the establishment is carried out by means of a Cooperative Establishment Deed made by a Notary in Indonesian. The notary who makes the Cooperative Establishment Deed is a Notary registered in the Ministry that administers Government affairs in the field of Cooperatives.

Juridically, the meaning of a Notary is regulated in Article 1 number 1 of Act No 2 of 2014 concerning Amendments to Act No 30 of 2004 concerning the Position of a Notary, which are:

"Notary is a public official who has the authority to make authentic deeds and has other powers as referred to in this Law or based on other Laws."

The notary itself has several types consisting of:

\footnotetext{
${ }^{1}$ Sinaga, Sahat HMT. (2019). NOTARIS \& BADAN HUKUM INDONESIA. Bekasi. Jala Permata Aksara. p. 85.

2 Sinaga, Sahat HMT. (2019). NOTARIS \& BADAN HUKUM INDONESIA. Bekasi. Jala Permata Aksara. p. 87.
} 
1. Notary, whose meaning is as described in Article 1 number 1 of Act No 2 of 2014 concerning Amendments to Act No 30 of 2004 concerning the Position of a Notary;

2. Temporary Notary Officer is a person who temporarily serves as a Notary to carry out the office of a Notary who has passed away; and

3. Substitute Notary is a person who is temporarily appointed as a Notary to replace a Notary who is on leave, is sick or temporarily unable to carry out his position as a Notary.

Notaries have the authority to carry out their profession as public officials as stipulated in statutory regulations. The authority of a notary is regulated in Article 15 of Act No 2 of 2014 concerning Amendments to Act No 30 of 2004 concerning the Position of a Notary. One of the notary's powers is to make authentic deeds regarding all actions, agreements and decisions required by laws and regulations and/or those desired by those concerned to be stated in authentic deeds, guarantee the certainty of the date of making the deed, keep the deed, provide grosse copies and excerpts of deeds, as long as the deeds are drawn up, they are not assigned or excluded from other officials or other people as stipulated by law.

Authority is often equated with authority. Syafrudin argues that there is a difference between authority (authority, gezag) and authority (competence, bevoegheid). Authority is referred to as formal power, power that comes from the power given by law, while authority only concerns a certain "onderdeel" (part) of the authority. Within the authority there are powers (rechtsbe voegdheden) ${ }^{3}$.

The authority of a Notary as stipulated in Article 15 of Act No 2 of 2014 also applies to Substitute Notaries and Temporary Notary Officers as described in Article 33 paragraph (2) of Act No 2 of 2014 which states that:

"The provisions that apply to Notaries as referred to in Article 4, Article 15, Article 16 and Article 17 also apply to Substitute Notaries and Temporary Notary Officers, unless this Law stipulates otherwise."

\section{Research Methods}

Legal research is divided into 2 (two), namely normative legal research and sociological legal research. Legal research conducted by examining library materials or secondary data is called normative legal research and research that examines primary data is called sociological legal research. ${ }^{4}$.

This type of research used by the author is normative legal research by examining library materials related to the authority of the substitute notary in making the cooperative's deed based on a qualitative approach. Sources and types of data in this study were obtained through secondary data. In order to obtain the necessary data, the author collects laws and regulations relating to the title that the author takes. In

\footnotetext{
${ }^{3}$ Erwinsyahbana, Tengku. Melinda.(2018).Kewenangan dan Tanggung Jawab Notaris Pengganti setelah Pelaksanaan Tugas dan Jabatan Berakhir. Volume 5. p. 311

${ }^{4}$ Zulfadli Barus.(2013). Analisis Filosofis Tentang Peta Konseptual Penelitian Hukum Normatif Dan

Penelitian Hukum Sosiologis. Volume 13. Nomor 2. p. 309
} 
addition, the author can obtain information through searching books and scientific works of legal experts.

\section{Results and Discussion}

3.1 Application of the Establishment of a Cooperative Deed according to Act No 17 of 2012 concerning Cooperatives

Act No 17 of 2012 concerning Cooperatives was made to repeal Act No 25 of 1992 which was passed on October 29, 2012 in Jakarta by President Dr. H. Soesilo Bambang Yudhoyono. Some of the points that become the background for the repeal of Act No 25 of 1992 concerning Cooperatives are:

1. The development of the national economy aims at realizing Indonesia's political and economic sovereignty through the management of economic resources in a climate of development and empowerment of cooperatives that have a strategic role in the national economic order in order to create an advanced, just and prosperous society based on Pancasila and the Constitution of the Republic of Indonesia. Indonesia 1945;

2. The development and empowerment of cooperatives in a Cooperative policy must reflect the values and principles of cooperatives as a means of joint efforts to fulfill the aspirations and economic needs of Members so that they grow strong, healthy, independent and resilient in the face of increasingly dynamic and challenging national and global economic developments;

3. Cooperative policies should always be based on a populist economy that involves, strengthens and develops cooperatives as mandated by the Decree of the People's Consultative Assembly of the Republic of Indonesia Number XVI/MPR/1998 concerning Political Economy in the Framework of Economic Democracy;

4. Act No 25 of 1992 concerning Cooperatives needs to be replaced because it is no longer in accordance with the legal requirements and development of Cooperatives, so that Act No 17 of 2012 concerning Cooperatives is formed.

So it can be concluded that the passing of Act No 17 of 2012 concerning Cooperatives is expected to be able to realize Indonesian cooperatives that are strong, healthy, independent and resilient in facing economic development both nationally and globally and are ready to face economic challenges.

In the process of establishing a cooperative, there are things that need to be considered according to Article 3 paragraph (2) of the Regulation of the State Minister for Cooperatives and Small and Medium Enterprises Number: 01/Per/M.KUKM/I/2006 which includes:

1. People who establish and later become members of cooperatives must have the same economic activities and/or interests;

2. Primary cooperative founders are Indonesian citizens, legally capable and capable of taking legal actions;

3. Secondary cooperative founders are managers of primary cooperatives who are given power from each primary cooperative to attend meetings for forming secondary cooperatives; 
4. The business to be carried out by a cooperative must be economically feasible, managed efficiently and be able to provide real economic benefits to members;

5. Sufficient capital must be available to support activities;

6. Managing Cooperatives; and

7. Business carried out by the cooperative ${ }^{5}$.

Cooperative establishment is carried out by means of a Cooperative Establishment Deed made by a Notary in the Indonesian language as regulated in Article 9 paragraph (1) of Act No 17 of 2012 concerning Cooperatives. Deed is a letter as evidence that is signed with the events that constitute the basis for a right or engagement, which was made from the beginning on purpose to prove ${ }^{6}$. Article 1868 of the Civil Code states that a deed is said to be authentic if the deed is made in the form prescribed by law and made by or in front of public officials (public officials) who are in power for it at the place where the deed is made. In this case, the public official who has the authority to draw up a deed of establishment of a cooperative is a notary. However, not all Notaries can make a Cooperative Establishment Deed. Notary who makes a Cooperative Establishment Deed is a Notary registered with the Ministry in the field of Cooperatives. And if in a sub-district there is no Notary, then a Cooperative Deed of Establishment can be drawn up by the District Head who has been legalized as the Cooperative Deed Making Official by the Minister.

Deeds are made to guarantee legal certainty of legal actions committed by the parties in the establishment of the cooperative. Notary deeds are not only a source for authenticity, notarial deeds are also the basis for the legality of the existence of the Notary deed concerned, with the following conditions:

a. The deed must be drawn up by (door) or in front of (ten overstaan) of a public official. If the notary deed only contains what the notary experienced and witnessed as a public official, then the deed is called a verbal deed or official deed (ambtelijke akten). One example of official deeds is the deed of minutes adopted by the Notary of a shareholder meeting of a Limited Liability Company. If a deed in addition to containing notes about what was witnessed or experienced by the Notary also contains what was agreed or determined by the parties before the Notary Public, then the deed is called "deed partij".

b. The deed must be published in the form prescribed by law. Regarding the form that has been determined by UUJN, the deed consists of the head of the deed, the body of the deed, the end of the deed. The parts of the deed which consist of the head of the deed and the end of the deed are parts that contain an authentic element, meaning that what is stated in the head of the deed and the end of the deed will determine whether the deed is made in the form determined by law or not.

c. The public official by or in front of whom the deed is drawn up must have the authority to make the deed. One of the conditions that must be fulfilled in order for

\footnotetext{
${ }^{5}$ Anugrah, Meidya. (2013). TINJAUAN HUKUM PENDIRIAN BADAN HUKUM KOPERASI. Edisi 5. Volume I.. p. 2.

${ }^{6}$ Ngadino. (2019). Tugas dan Tanggung Jawab Jabatan Notaris di Indonesia. Semarang: UPT Penerbitan Universitas PGRI Semarang Press. p. 78
} 
a deed to gain authenticity is the authority of the notary concerned to make the deed ${ }^{7}$.

The Notary Deed of Establishment of a Cooperative contains the Articles of Association and information relating to the Establishment of a Cooperative which at least contains:

1. Full name, place and date of birth, place of residence, and occupation of individual founders or name, domicile, and complete address as well as number and date of legalization of the founding Cooperative legal entity for Secondary Cooperatives; and

2. The composition, full name, place and date of birth, place of residence, and occupation of the Supervisor and Management who were first appointed.

The application for a Cooperative Establishment Deed is submitted in writing by the founders together or their proxies to the Minister to obtain approval as a legal entity.

\subsection{Authority in Preparing Cooperative Establishment Deeds}

Notary is a public position that is attached to a person on the basis of public trust in managing everything related to legal actions taken. Notaries have the authority, obligations and rights they have in carrying out their positions as public officials as stipulated in Act No 2 of 2014 in conjunction with Act No 30 of 2004 concerning Notary Position.

According to Prof. Dr. H. Salim HS., SH, MS, Notary, which in English is called a notary, while in Dutch it is called van notary, has a very important role in legal traffic, especially in the field of civil law because a Notary is a public official. , who has the authority to make authentic deeds and other powers ${ }^{8}$. Meanwhile, the definition of a Notary according to Article 1 number 1 of Act No 2 of 2014 concerning Amendments to Act No 30 of 2004 concerning the Position of a Notary is:

"Notary is a public official who has the authority to make authentic deeds and has other powers as referred to in this Law or based on other Laws."

Notaries have a very important position and role in the life of the nation and state, because they have the authority or authority that has been determined in the laws and regulations. ${ }^{9}$. The notary profession itself has certain characteristics, including:

a. Notary is a position

The position of a notary is protected by legal regulations with the intention of helping and serving people who need authentic written evidence regarding conditions, events or legal actions. This is regulated in Act No 30 of 2004 concerning the Position of Notary Public. So that everything related to notaries in Indonesia refers to these laws and regulations ${ }^{10}$.

b. Notaries have certain powers

\footnotetext{
${ }^{7}$ Ngadino. (2019). Tugas Dan Tanggungjawab Jabatan Notaris Di INDONESIA. Semarang: UPT Penerbitan Universitas PGRI Semarang Press. p. 79

${ }^{8}$ HS, Salim. (2018). Peraturan Jabatan Notaris. Jakarta. Sinar Grafika. P. 14.

${ }^{9}$ Ibid. Pg 26.

${ }^{10}$ Witasari, Aryani. (2012). Mpd Bukan Advokat Para Notaris Berdasarkan Uu No.30 Tahun 2004 Tentang Jabatan Notaris. P. 885.
} 
The notary's authority, which in English is called the notary of authority, while in Dutch it is called de notary autoriteit, namely everything related to the power inherent in a notary. ${ }^{11}$.

c. Appointed and dismissed by the Government

Although administratively appointed and dismissed by the Government, it does not mean that a notary is a subordinate of the Government. So that in carrying out his position, the notary is independent and does not take sides with anyone, and does not depend on anyone who causes the Government or other parties not to interfere with the notary in carrying out his position. ${ }^{12}$.

In Article 1 of Act No 2 of 2014 concerning Amendments to Act No 30 of 2004 concerning the Position of Notary Public, states that the types of Notary consist of:

a. Notary Public

Notary is a public official who has the authority to make authentic deeds and has other powers as referred to in this Law or based on other Laws.

b. Temporary Notary Officer

Temporary Notary Officer is a person who temporarily serves as a Notary to carry out the position of a Notary who has passed away.

c. Substitute Notary

Substitute Notary is a person who is temporarily appointed as a Notary to replace a Notary who is on leave, is sick or temporarily unable to carry out his position as a Notary.

Notary, as a public official in carrying out the authority, rights and obligations related to the management of everything concerning the legal actions carried out by the Client, of course guided by Act No 2 of 2014 in conjunction with Act No 30 of 2004 concerning Notary Position. Notary's authority, which in English is called the notary of authority, while in Dutch it is called de notary autorite it, which is related to the power inherent in a Notary. ${ }^{13}$. Notary's authority is regulated in Article 15 of Act No 2 of 2014 in conjunction with Act No 30 of 2004 concerning the Position of a Notary which states that:

(1) The notary is authorized to make authentic deeds regarding all actions, agreements and stipulations required by the laws and regulations and/or that the interested party wants to be stated in the authentic deed, guarantees the certainty of the deed creation date, keeps the deed, gives grosse. copies and excerpts of deeds, as long as the deeds are drawn up, they are not assigned or excluded from other officials or other persons stipulated by law.

(2) The notary is also authorized:

a. Ratify the signature and determine the certainty of the date of the letter under the hand by registering in a special book;

b. Submitting letters under hand by registering in a special book;

c. Make a copy of the original letter under hand in the form of a copy containing the description as written and described in the letter concerned;

\footnotetext{
${ }^{11}$ HS, Salim. (2018). Peraturan Jabatan Notaris. Jakarta: Sinar Grafika. Pg 26.

12 Witasari, Aryani. (2012). Mpd Bukan Advokat Para Notaris Berdasarkan Uu No.30 Tahun 2004 Tentang Jabatan Notaris. Page 885.

${ }^{13}$ HS, Salim. (2018). Peraturan Jabatan Notaris. Jakarta: Sinar Grafika. Pg 26
} 
d. Conduct validation of the compatibility of the photocopy with the original letter;

e. Providing legal education in connection with making deeds;

f. Making deeds related to land; or

g. Prepare a deed of auction minutes.

In practice, sometimes the Notary Public is unable to carry out his/her duties in making a Notary deed because of an obstacle. These obstacles can be in the form of illness or an urgent situation that requires the Notary to take leave. Even worse, the Notary is no longer able to carry out his duties because of his death. To maintain the continuity of the Notary's position, a Notary Public or Temporary Notary Officer is appointed. In relation to the obligation for a Notary who takes leave of absence to appoint a substitute notary, it is a common thing. Because if the Notary on leave does not appoint a replacement, then the activities at the Notary's office will stagnate, so that it will be detrimental to customers or clients who desperately need Notary services. ${ }^{14}$.

Substitute Notary Public also has the authority, rights and obligations in carrying out his/her position to avoid arbitrary actions. This authority is regulated in Article 33 paragraph (2) Act No 2 of 2014 in conjunction with Act No 30 of 2004 concerning the Position of a Notary which states that:

"The provisions that apply to Notaries as referred to in Article 4, Article 15, Article 16 and Article 17 also apply to Substitute Notaries and Temporary Notary Officers, unless this Law stipulates otherwise."

From the article above it can be concluded that the authority, obligations and prohibitions of the Notary Public also apply to the Substitute Notary Public. The Substitute Notary exercises the authority of the Notary Public and can be said to act in his position as Notary Public when replacing the Notary concerned because the product produced is also an authentic deed ${ }^{15}$. So that the Substitute Notary can also make a Cooperative Establishment Deed as long as the Substitute Notary is registered with the Ministry which administers government affairs in the field of cooperatives.

\section{Closing}

Based on the above research, the writer concludes that Cooperative establishment is carried out by a Cooperative Establishment Deed which is made by a Notary registered with the Ministry of Cooperatives in Indonesian and a substitute Notary can also make a Cooperative Establishment Deed as long as the Substitute Notary is registered with the Ministry which administers Government affairs in the field of Cooperatives. Through this research, the author argues that it is necessary to conduct socialization regarding cooperatives to the community, starting from the advantages of cooperatives, requirements, the establishment process to the approval of cooperatives to attract public interest in economic activities through cooperatives. In addition, it is better to increase the number of Notaries and Substitute Notaries registered with the Ministry in the field of Cooperatives and to increase knowledge regarding the Deed of

\footnotetext{
${ }^{14}$ Suharto, Sakti. Syamsul Bachri, Hasbir Paserangi. (2017). Wewenang Notaris Pengganti Atas Pembuatan Akta Koperasi. Vol. 6.No.1 Pg 76.

${ }^{15}$ Ibid.
} 
Establishment of Cooperatives in order to facilitate the community in establishing cooperatives.

\section{References}

Books:

[1] Anugrah, Meidya. (2013). Tinjauan Hukum Pendirian Badan Hukum Koperasi. Edisi 5. Volume I

[2] Erwinsyahbana, Tengku. Melinda.(2018).Kewenangan dan Tanggung Jawab Notaris Pengganti setelah Pelaksanaan Tugas dan Jabatan Berakhir. Volume 5

[3] Hs, Salim. (2018). Peraturan Jabatan Notaris. Jakarta. Sinar Grafika.

[4] Ngadino. (2019). Tugas Dan Tanggungjawab Jabatan Notaris Di Indonesia. Semarang: Upt Penerbitan Universitas Pgri Semarang Press.

[5] Sinaga, Sahat Hmt. (2019). Notaris \& Badan Hukum Indonesia. Bekasi. Jalan Permata Aksara.

[6] Suharto, Sakti. Syamsul Bachri, Hasbir Paserangi. (2017). Wewenang Notaris Pengganti Atas Pembuatan Akta Koperasi. Vol. 6.No.1

[7] Witasari, Aryani. (2012). Mpd Bukan Advokat Para Notaris Berdasarkan Uu No.30 Tahun 2004 Tentang Jabatan Notaris.

[8] Zulfadli Barus.(2013). Analisis Filosofis Tentang Peta Konseptual Penelitian Hukum Normatif Dan Penelitian Hukum Sosiologis. Volume 13. Nomor 2

Regulation:

[1] Constitution. 2012. Act No 17 of 2012 Concerning

[2] Cooperatives.

[3] Constitution. 2014. Act No 2 of 2014 Concerning

[4] Amendments to Act No 30 of 2004 Concerning Position

[5] Notary Public. 